\title{
Field and Numerical Investigation on the Coal Pillar Instability of Gob-Side Entry in Gently Inclined Coal Seam
}

\author{
Xupeng Ta, ${ }^{1,2}$ Zhijun Wan $\mathbb{D}^{1,2}$ Yuan Zhang ${ }^{10},{ }^{1,2}$ Peng Shi, ${ }^{1,2}$ Zejie Wei, ${ }^{1,2}$ Xin Sun, ${ }^{1,2}$ \\ and Liangliang $\mathrm{Jia}^{3}$ \\ ${ }^{1}$ Key Laboratory of Deep Coal Resource Mining (China University of Mining \& Technology), Ministry of Education of China, \\ Xuzhou 221116, China \\ ${ }^{2}$ School of Mines, China University of Mining \& Technology, Xuzhou 221116, China \\ ${ }^{3}$ Chensilou Coal Mine, Henan Energy Chemical Group Yongmei Company, Yongcheng 476600, China
}

Correspondence should be addressed to Zhijun Wan; zhjwan@cumt.edu.cn and Yuan Zhang; zhangyuan@cumt.edu.cn

Received 30 May 2021; Accepted 14 July 2021; Published 28 July 2021

Academic Editor: Ali Lakirouhani

Copyright (c) 2021 Xupeng Ta et al. This is an open access article distributed under the Creative Commons Attribution License, which permits unrestricted use, distribution, and reproduction in any medium, provided the original work is properly cited.

\begin{abstract}
In order to study the coal pillar stability of gob-side entry in gently inclined coal seam, a comprehensive method including theoretical analysis, numerical modeling, and field monitoring was applied to study its fracturing and instability mechanism. The results show that the uneven horizontal stress was the internal cause of entry asymmetric deformation and failure in inclined coal seam. In gently inclined coal seam, the rotation movement of the main roof and stress distribution were closely related to inclination of the coal seam. Based on the asymmetric deformation characteristics and mechanisms of entry, a collaborative control technology of roof cutting for pressure relief and support strengthening has been put forward. The research results have practical significance for revealing the mechanism of entry damage in gently inclined coal seam mining and proposing engineering measures to prevent coal pillar damage and disaster occurrence.
\end{abstract}

\section{Introduction}

With the increasing energy demand and mining intensity, the shallow coal resources gradually exhausted. In order to improve recovery rate of coal resources in China, gob-side entry driving (GED) techniques are widely adopted in the process of entry excavation. The stability of coal pillar is the key of the GED technique. In recent decades, the research on mechanical properties of coal pillar mainly reveals the dynamic mechanical state of coal pillar through field observation, theoretical analysis, similar material simulation test, and numerical simulation, and then puts forward the control methods of changing the width of coal pillar, optimizing support parameters and improving the properties of surrounding rock [1-7]. Scholars have studied the relationship between ground stress distribution and roadway fracture development by using comprehensive monitoring system and borehole camera exploration device and developed a strictly calibrated numerical model to simulate the stress redistribution under different conditions $[8,9]$. Das et al. [10] developed generic analytical solutions to estimate the strength of the inclined coal pillars, deriving mathematical models to obtain the confining stress in the coal pillar and the corresponding peak stress at the time of its failure. Gao and $\mathrm{Ge}$ [11] proposed a composite rock mass method based on the mechanical method to obtain the derived stress not only for the cohesive constraining forces of the coal pillar but also for the rock mass of the roof and floor. Prassetyo et al. [12] analyzed the effect of coal-entry friction on the strength of coal pillar by laboratory tests and modified the empirical equation for the strength of coal pillar. Dai et al. [13] studied the intelligent identification method for the stability of coal pillar in the section, analyzed load transfer law of the overlying strata in the upper part of coal pillar, and calculated the optimal value of the coal pillar using the Delphi index evaluation system. Liu et al. [14] improved the method of coal pillar fracture digitization and established the model of coal pillar stability evaluation. Gao [15] proposed a new 
method to comprehensively study the stability of the strip coal pillar based on the elastic-plastic mechanics theories and the previous studies of the limiting equilibrium method.

Compared with the flat coal pillars, the stress environment of the inclined coal pillars is more complex because of the asymmetric stress distribution. Das et al. $[16,17]$ analyzed the failure stress states within the coal pillars having different dip angles and elucidated the procedures to estimate the strength of the inclined coal pillars by the numerical modeling technique. Zhao et al. [18] analyzed the mechanical characteristics of narrow coal pillars' gob-side entry in inclined coal seams and obtained the damage form of coal pillars with different widths during excavation. Chen and Wang [19] analyzed surrounding rock deformation characteristics of gob-side entry driving in deep inclined coal seam and revealed the asymmetric large deformation characteristics of such roadway. Zhang et al. [20] analyzed the support stress distribution law near the gob side and investigated the relationship between the surrounding rock stress distribution of the roadway and the coal pillar width by the numerical method. A review of the previous studies indicated that (1) the inclination angle of the coal seam has a significant influence on the stability of the coal pillar and (2) there was less research on the distribution pattern of coal pillar abutment pressure under the influence of dip angle of coal seam. Thus, it is necessary to take the abutment pressure, generated by roof overburden structure in gently inclined coal seam, into account in examining coal pillar stability.

In this study, numerical simulations were conducted to examine the stability of a mining entry with $2.0 \mathrm{~m}$ section coal pillars under the influence of dip angle of coal seam. A surrounding rock structure model was established to investigate dynamic mechanical characteristics of a coal pillar in the gently inclined coal seam. According to the theoretical and numerical results, the dynamic mechanical state of the coal pillar was studied in detail, and a method for controlling the entry stability was proposed.

\section{Geological Setting and Mining Conditions}

In this study, the 21015 entry with $2.0 \mathrm{~m}$ section coal pillars in the 21015 working face of the Chensilou coal mine, Henan Province, was used as the research object, as shown in Figure 1(a). The coal seam dip angle was $18^{\circ}$, and the average thickness and burial depth were $2.66 \mathrm{~m}$ and $400 \mathrm{~m}$, respectively. According to the drilling records, the immediate roof and floor were sandy mudstone with average thickness of $2.76 \mathrm{~m}$ and $3.3 \mathrm{~m}$, and the main roof and floor were medium-fine sandstone with average thickness of $20.4 \mathrm{~m}$ and $4.83 \mathrm{~m}$. The $2.0 \mathrm{~m}$ section coal pillar was reserved between the 21015 and 21011 working faces. During the actual mining process, after the end of the 21011 working face, the 21015 entry began to excavate along the edge of the gob. The 21015 entry was supported by anchor-mesh-cable system, as shown in Figure 1(b). The roof of the entry was supported by $22 \times 2200 \mathrm{~mm}$ bolts and $21.6 \times 8300 \mathrm{~mm}$ cables. The pillar rib and the solid coal rib of the entry were supported by $16 \times 2200 \mathrm{~mm}$ and $22 \times 2200 \mathrm{~mm}$ bolts, respectively. The roof bolt and rib bolt spacings for the entry was $880 \mathrm{~mm}$ and $700 \mathrm{~mm}$, respectively, and roof cable spacing was $1600 \mathrm{~mm}$, as shown in Figure 1(c).

\section{Methodology}

3.1. In Situ Monitoring. To fully understand the asymmetric deformation law of the entry in the gently inclined coal seam, surface displacement monitoring stations and borehole measuring points were arranged in the tail entry, as shown in Figure 2. The borehole measurement points No. 1 and No. 2 were located at $12 \sim 15 \mathrm{~m}$ and $28 \sim 30 \mathrm{~m}$ in the advancing direction of 21015 working face, and only three of them can be fully observed. The distance between each stations was $25 \sim 30 \mathrm{~m}$ and the first monitoring station was located $60 \mathrm{~m}$ ahead the 21015 working face. According to the site situation, the borehole measurement point No. 1 was set within the advanced support range, and the borehole measurement point No. 2 was set outside the range as a comparison. As the working face advances, the observation data of each surface displacement monitoring station can be compared with the observation data of borehole measuring points.

3.2. Numerical Modeling. To fully understand the stability of a mining entry with $2.0 \mathrm{~m}$ section coal pillars under the influence of dip angle of coal seam, a FLAC ${ }^{3 \mathrm{D}}$ numerical simulation with the "Mohr-Coulomb criterion" based on the engineering geological conditions of 21015 working face was established as shown in Figure 3. The dimension of the numerical model was $150 \times 150 \times 150 \mathrm{~m}$ (width $\times$ height $\times$ length). The four sides and the bottom of the model were constrained by displacement, and the top boundary was applied with a vertical stress of $12.6 \mathrm{MPa}$. The physical and mechanical rock mass parameters were obtained via laboratory tests and previously performed research works [21], as shown in Table 1. The simulation process was as follows: (1) excavate the mining entry of the 21011 working face; (2) mine the 21011 working face; (3) fill the caved zone with the double-yield model; (4) excavate the mining entry of the 21015 working face; and (5) mine the 21015 working face (Figure 3).

\section{Results and Discussion}

4.1. In Situ Deformation Test Results and Discussion. The observation results are shown in Figure 4. Based on the statistics of observation results shown in Figure 4(a), it was found that the internal damage of the coal pillar can be divided into three areas: relatively complete area $(<40 \mathrm{~cm})$, limited damage area $(40 \sim 80 \mathrm{~cm})$, and loose failure area $(>80 \mathrm{~cm})$. It can be seen that the coal pillar was relatively complete within $40 \mathrm{~cm}$ of the shallow part, and there were a few macroscopic cracks; the coal pillar was relatively broken within the range of $40 \sim 80 \mathrm{~cm}$, the hole wall was in a fragmented state, and most of the blocks do not peel off; the area within the range of $40 \sim 80 \mathrm{~cm}$ appears loosely broken, mostly blocky, with large blockiness, and the small hole walls were peeled off. The roof observation results are shown in Figure 4(b); it was found that in the range of $0 \sim 22 \mathrm{~cm}$, many 


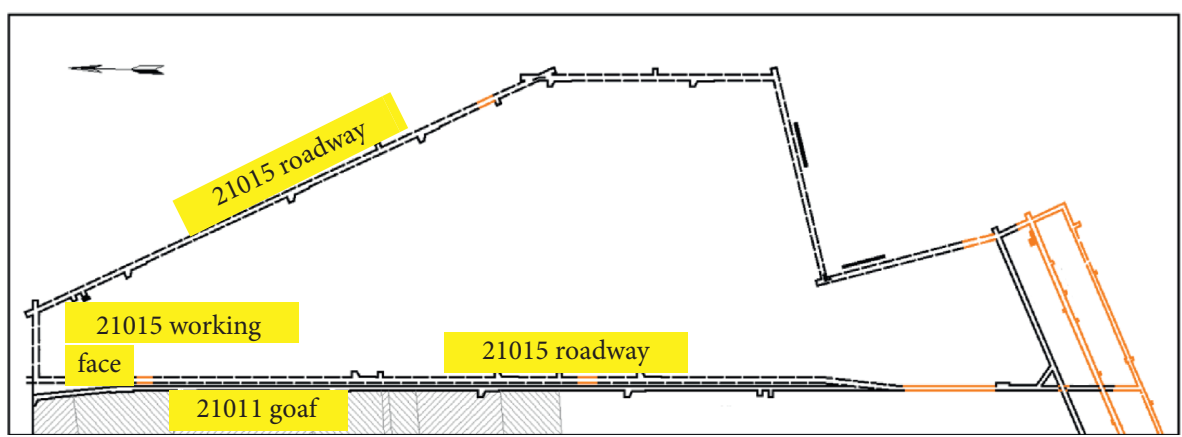

(a)

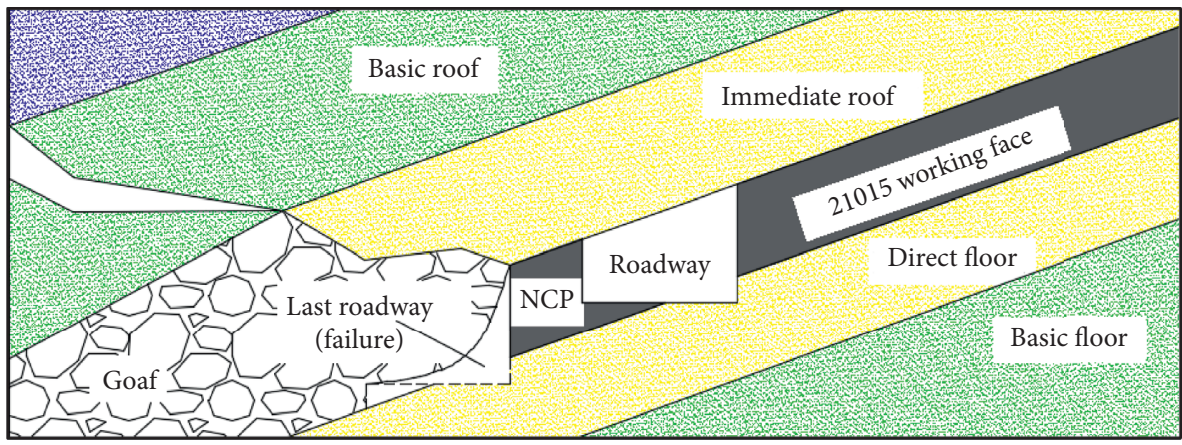

(b)

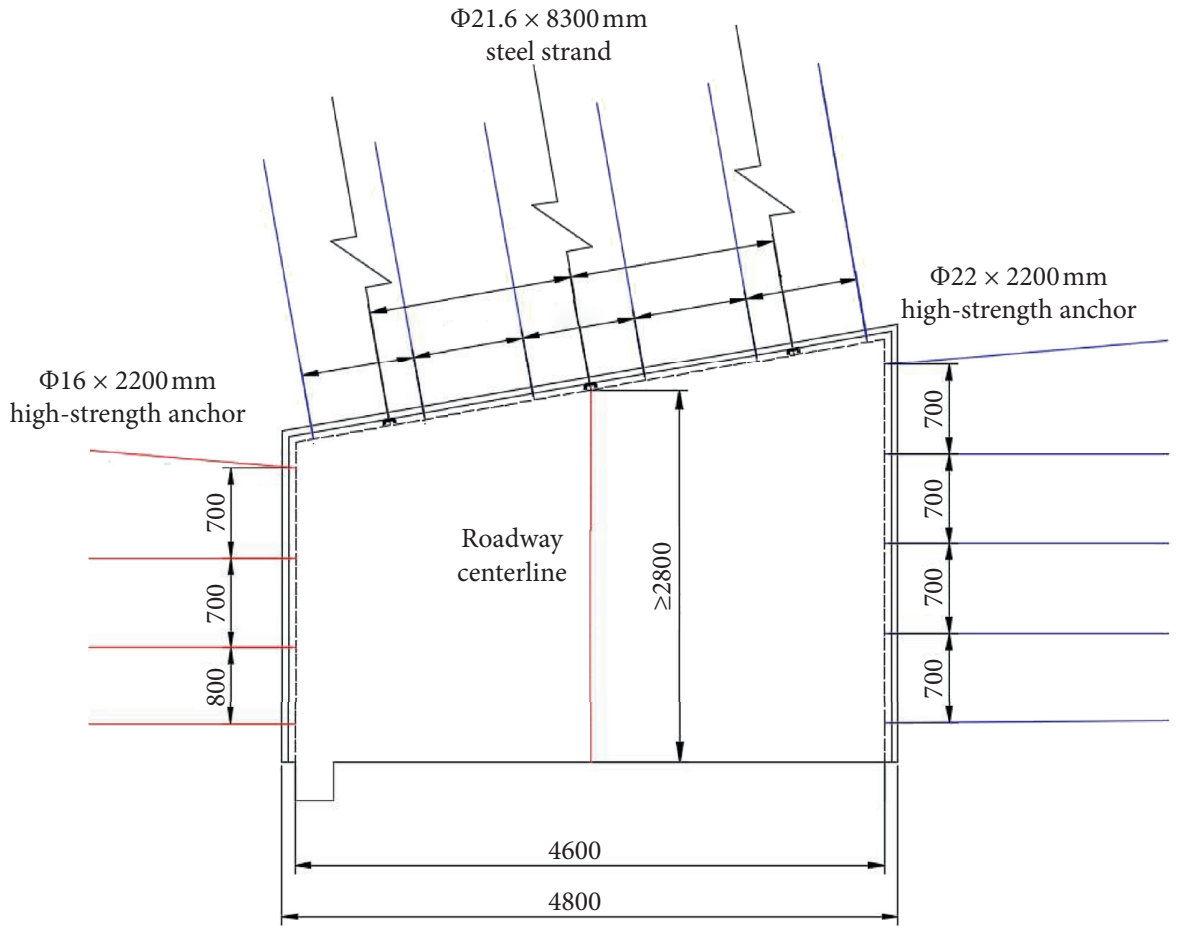

(c)

Figure 1: Position of the gob-side entry and support parameters.

cracks were distributed in the hole wall, and the roof was relatively complete; in the range of $0.68 \sim 1.56 \mathrm{~m}$, longer cracks penetrated the hole wall and formed fragmentation areas; in the further range, the hole wall was completed. From the above data analysis, we can see that with the increase of observation depth, entry deformation became more and more serious, and within a certain inclination, main roof fracture line was located above the coal pillar.

Figure 5 shows deformation monitoring curve of entry. It can be seen that the deformation law of surrounding rock monitored by stations was similar. As the working face advances, the deformation of the roadway gradually 


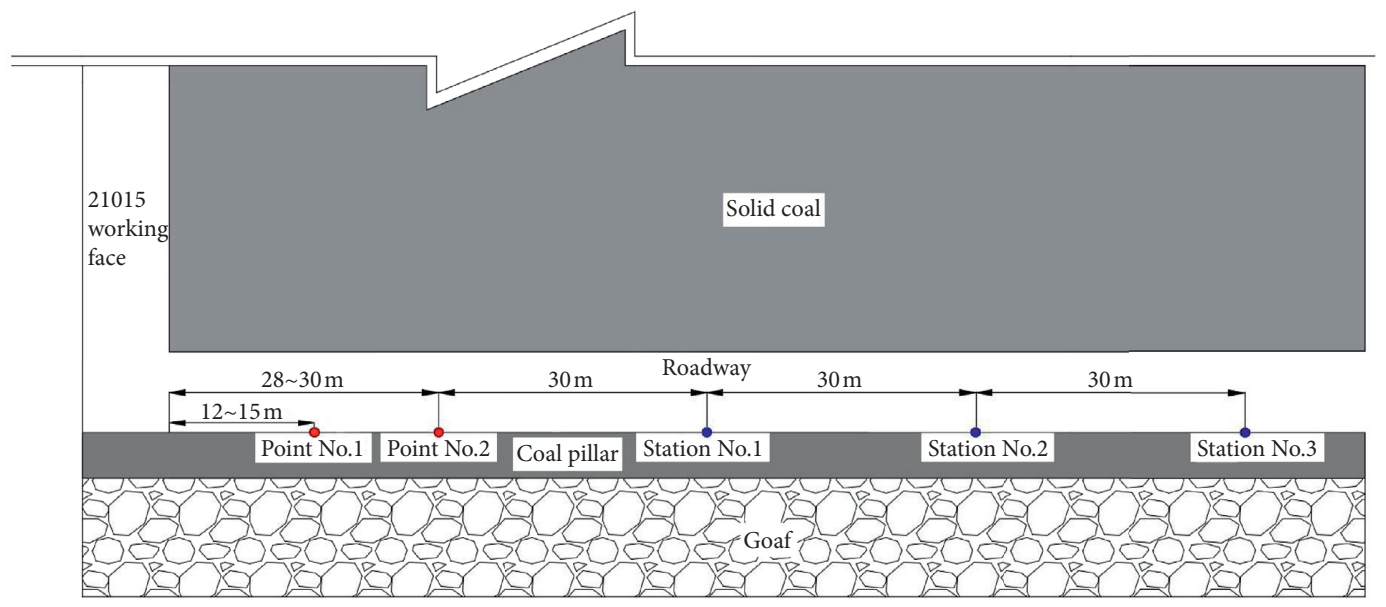

FIgURE 2: Monitoring stations and measuring point arrangement.

TABLE 1: Numerical simulation parameters.

\begin{tabular}{|c|c|c|c|c|c|c|c|c|}
\hline $\begin{array}{l}\text { Rock } \\
\text { layer }\end{array}$ & $\begin{array}{l}\text { Rock } \\
\text { type }\end{array}$ & $\begin{array}{l}\text { Average } \\
\text { thickness } \\
(\mathrm{m})\end{array}$ & $\begin{array}{l}\text { Density } \\
\left(\mathrm{kg} / \mathrm{m}^{3}\right)\end{array}$ & $\begin{array}{c}\text { Bulk } \\
\text { modulus } \\
(\mathrm{GPa})\end{array}$ & $\begin{array}{l}\text { Shear modulus } \\
(\mathrm{GPa})\end{array}$ & $\begin{array}{c}\text { Tensile } \\
\text { strength } \\
(\mathrm{MPa})\end{array}$ & $\begin{array}{c}\text { Internal } \\
\text { stress } \\
(\mathrm{MPa})\end{array}$ & $\begin{array}{l}\text { Internal friction } \\
\text { angle }\left({ }^{\circ}\right)\end{array}$ \\
\hline $\begin{array}{l}\text { Overlying } \\
\text { strata }\end{array}$ & - & 385 & 2500 & 12.00 & 7.8 & 1.6 & 2.4 & 28 \\
\hline Main roof & $\begin{array}{l}\text { Middle-fine } \\
\text { sandstone }\end{array}$ & 4.83 & 2680 & 12.23 & 8.4 & 2.19 & 9.1 & 36 \\
\hline $\begin{array}{l}\text { Immediate } \\
\text { roof }\end{array}$ & $\begin{array}{c}\text { Sandy } \\
\text { mudstone }\end{array}$ & 3.3 & 2659 & 2.51 & 1.36 & 1.70 & 1.9 & 21 \\
\hline Coal & - & 3 & 1212 & 0.79 & 0.24 & 1.52 & 3.46 & 22 \\
\hline $\begin{array}{l}\text { Immediate } \\
\text { floor }\end{array}$ & $\begin{array}{c}\text { Sandy } \\
\text { mudstone }\end{array}$ & 2.76 & 2659 & 2.51 & 1.36 & 1.70 & 1.9 & 21 \\
\hline Main floor & $\begin{array}{l}\text { Middle-fine } \\
\text { sandstone }\end{array}$ & 20.04 & 2680 & 12.23 & 8.4 & 2.19 & 9.1 & 36 \\
\hline
\end{tabular}

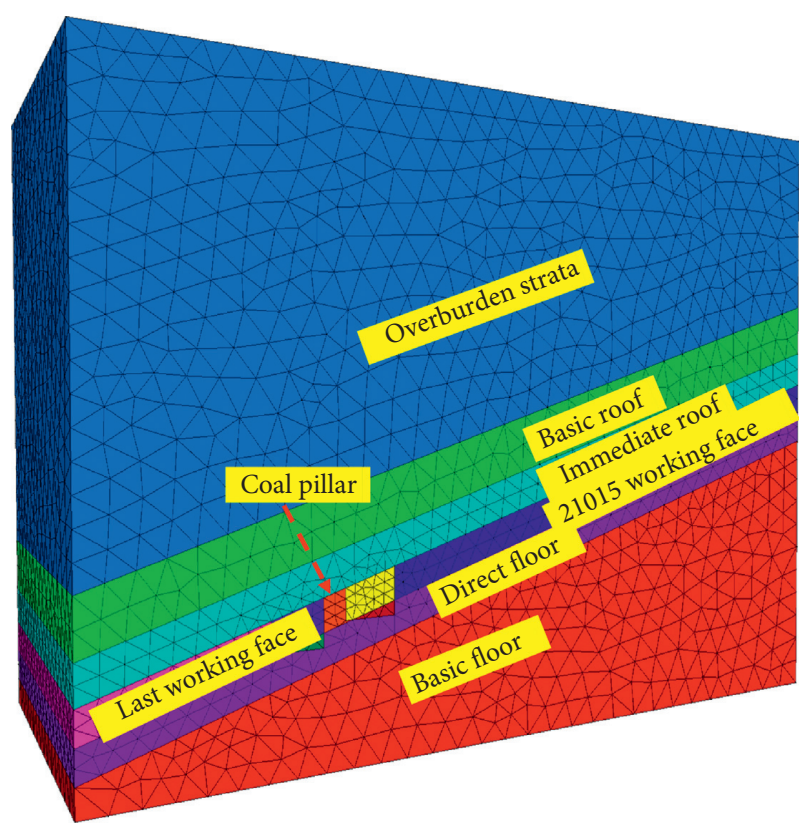

FIGURE 3: Sketch map of numerical model. increases, with the deformation of the rib up to $140 \mathrm{~mm}$ and the deformation of the roof and floor up to $64 \mathrm{~mm}$. Compared with the solid coal side, the surrounding rock deformation of coal pillar side was larger, and the deformation of the roof was slightly larger than that of the floor. The surge in deformation rate was observed at all stations and occurred $30-45 \mathrm{~m}$ from the working face, where the entry was subjected to front abutment pressure of working face. At a distance of about $30 \mathrm{~m}$ and $15 \mathrm{~m}$ from the working surface, the deformation of the coal pillar side and the roof was consistent with the failure of the borehole observation. From the above analysis, it can be concluded that the asymmetry deformation of entry is obviously, affected by the front abutment pressure of 21015 working face.

4.2. Structure Characteristics of Roadway Surrounding Rock in Gently Inclined Coal Seam. It is generally believed that the abutment pressure distribution significantly affects the stability of the roadway. In order to reveal the force condition of roadway under the influence of dip angle of coal seam, the structure characteristics of roadway surrounding rock were investigated, as shown in Figure 6. 


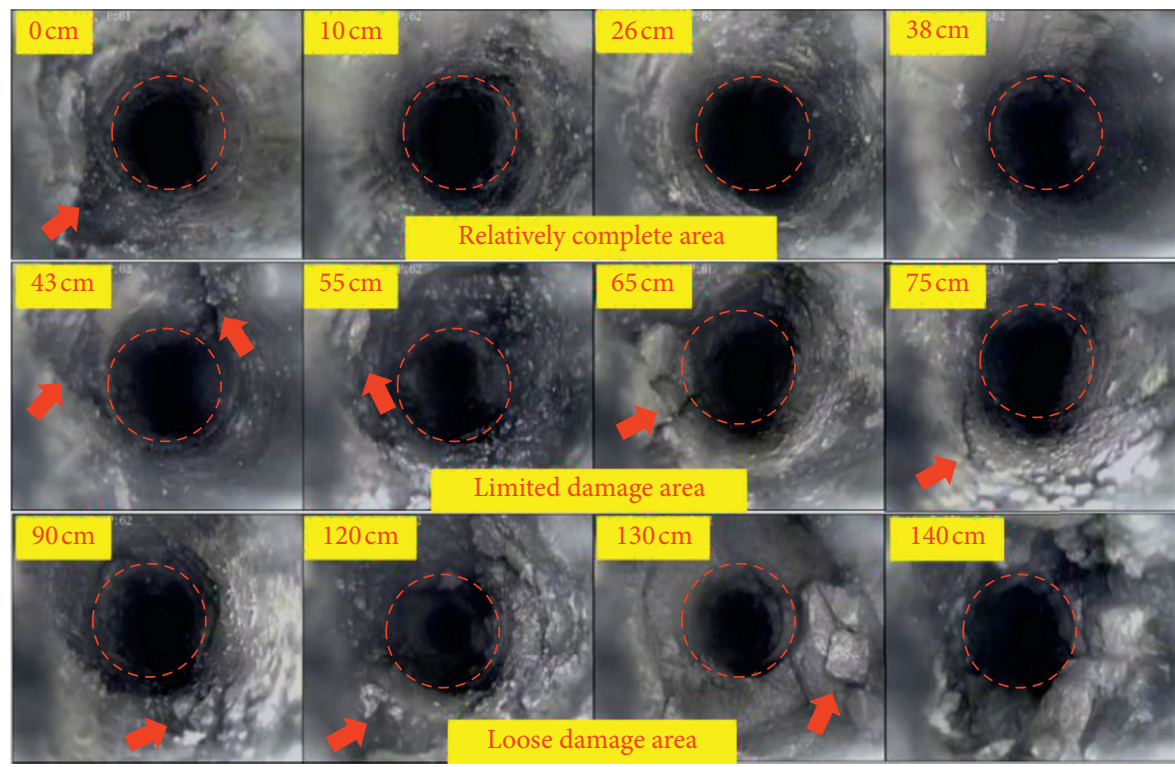

(a)

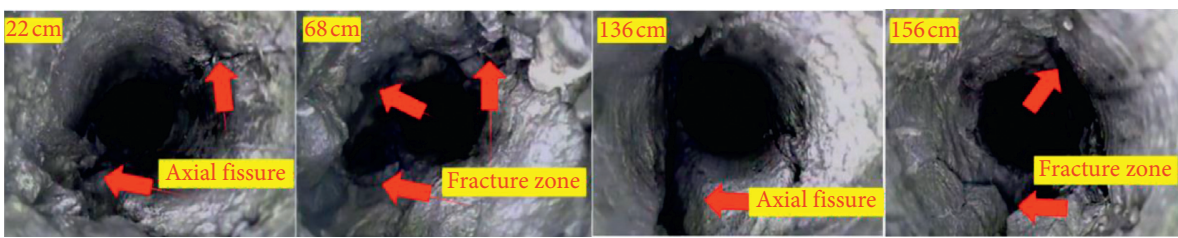

(b)

Figure 4: Observation of the inside of the coal pillar. (a) No. 1 point. (b) No. 2 point.

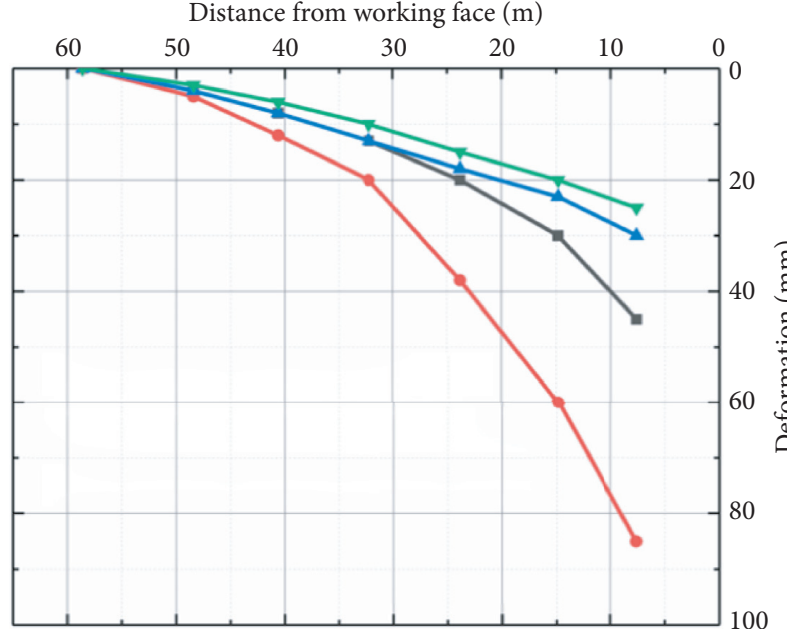

$\rightarrow$ Deformation of solid coal side $\rightarrow-$ Deformation of roof $\rightarrow$ Deformation of coal pillar side $\rightarrow$ Deformation of floor

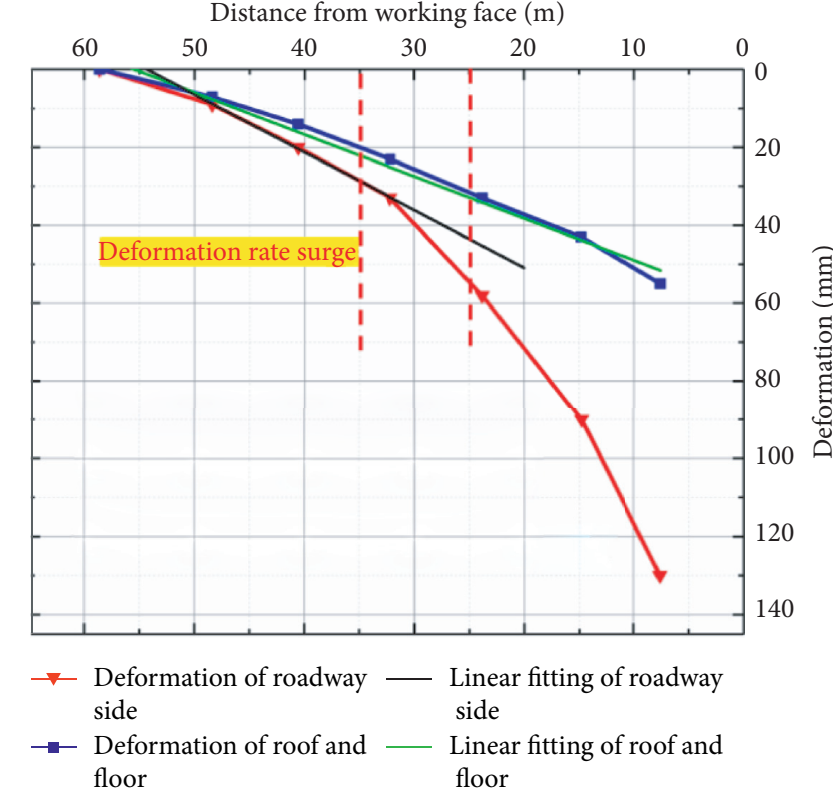

(a)

FIGURE 5: Continued. 


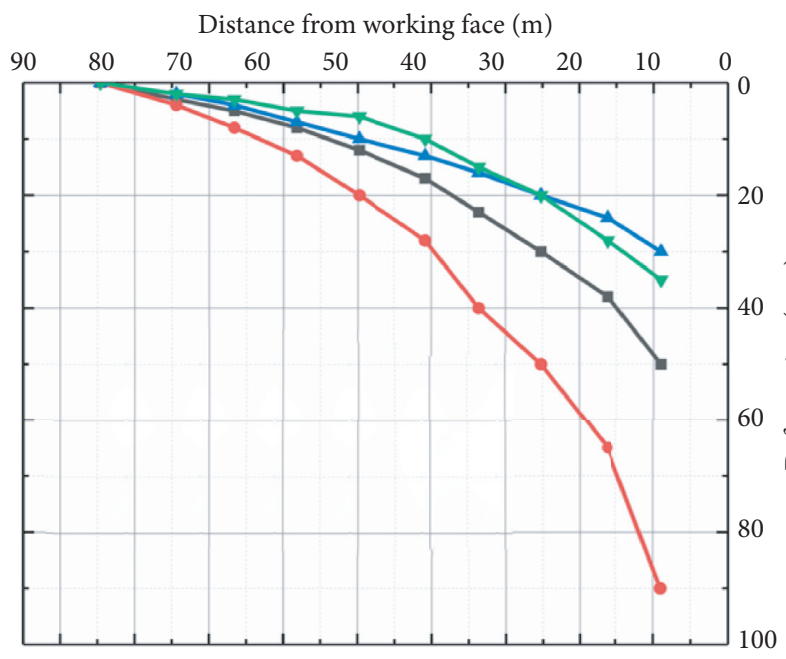

- Deformation of solid coal side $\_$Deformation of roof

$\rightarrow$ Deformation of coal pillar side $\longrightarrow$ Deformation of floor

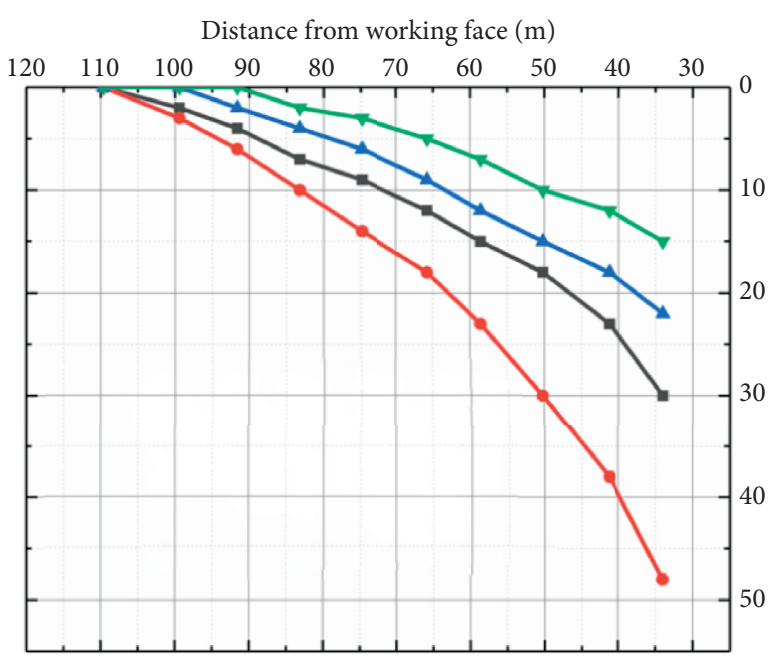

$\rightarrow$ Deformation of solid coal side $\rightarrow$ Deformation of roof $\rightarrow$ Deformation of coal pillar side $\rightarrow$ Deformation of floor

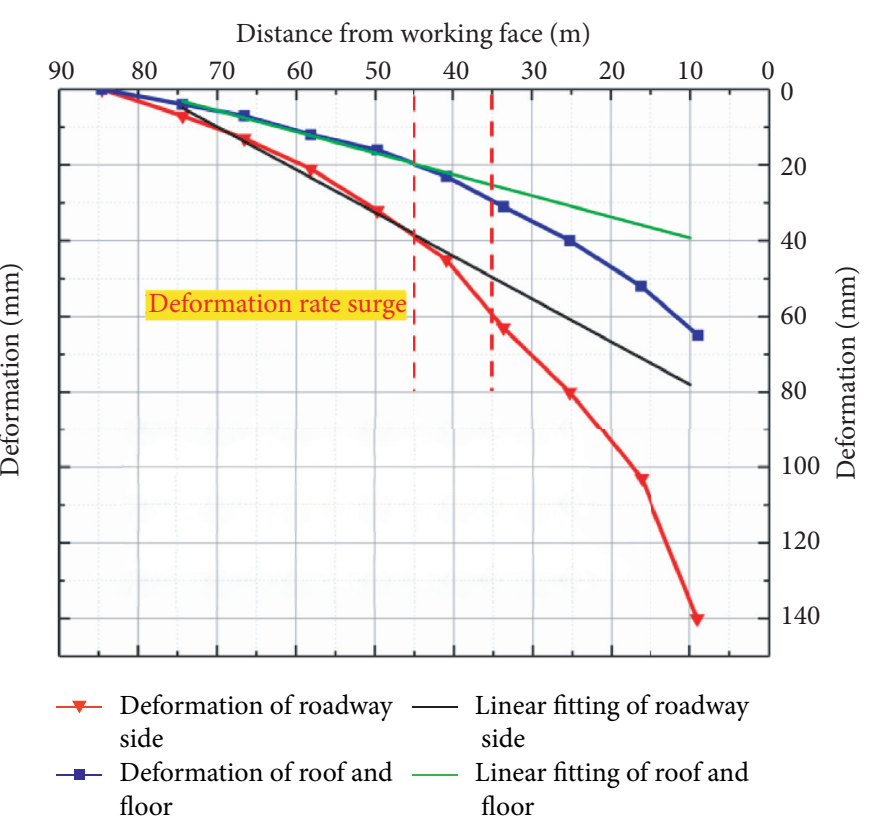

(b)

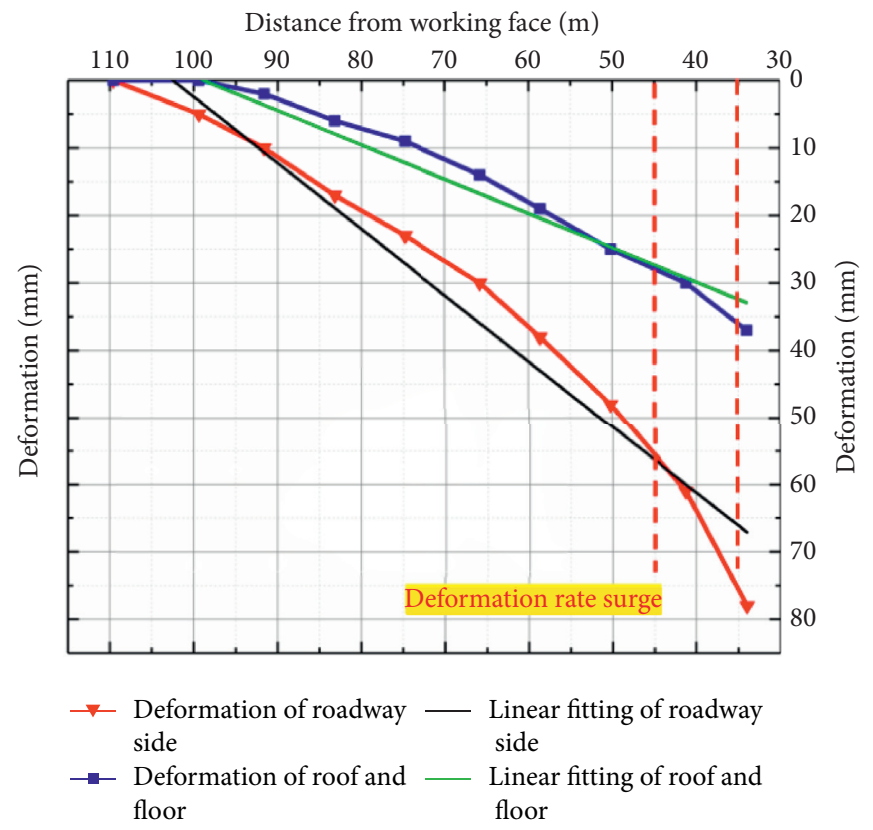

(c)

FIGURE 5: Entry deformation monitoring curve. (a) 1\# monitoring station. (b) 2\# monitoring station. (c) 3\# monitoring station.

The fracture position of key block B can be obtained from the limit equilibrium theory, and the expression is as follows $[22,23]$ :

$$
X_{0}=\frac{\lambda M}{2 \tan \varphi} \ln \left(\frac{k \gamma H+(c / \tan \varphi)}{(c / \tan \varphi)+(P / \lambda)}\right) .
$$

The position where the highest pressure of the coal pillar occurs can be calculated by the following formula:

$$
x_{0}=\frac{M \lambda}{2 \tan \varphi_{0}} \ln \left[\frac{\lambda\left(k \gamma H \cos \alpha \tan \varphi_{0}+2 c-m \gamma \sin \alpha\right)}{\lambda(2 c-m \gamma \sin \alpha)+2 P \tan \varphi_{0}}\right] \text {, }
$$

where $X_{0}$ is the distance between the fracture line of key block $\mathrm{B}$ and gob, $\mathrm{m} ; x_{0}$ is the place where peak stress occurs; $c$ is the cohesion of the coal, $3.46 \mathrm{MPa} ; \varphi$ is the inner friction angle of the coal, $22^{\circ} ; P$ is the support resistance of the coal 


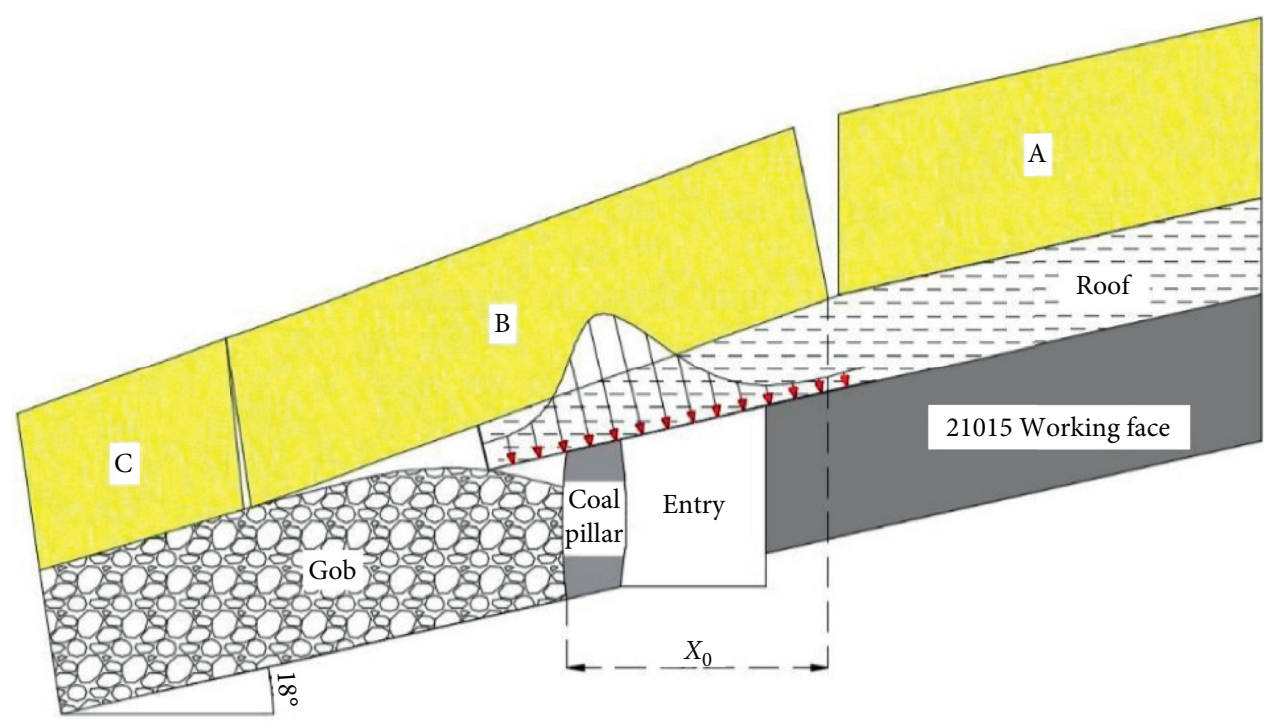

Figure 6: Structure characteristics of roof strata in gently inclined coal seam.

pillar, $0.25 \mathrm{MPa} ; \lambda$ is the side pressure coefficient, $1.2 ; k$ is the maximum stress concentration factor, $1.2 \sim 1.4 ; \gamma$ is the average density of the overburden, $25 \mathrm{kN} / \mathrm{m}^{3} ; H$ is the depth of the coal seam, $400 \mathrm{~m}$; and $M$ is the coal seam thickness, $3.0 \mathrm{~m}$.

According to Equation (1) and (2), $X_{0}$ was $3.83 \sim 4.19 \mathrm{~m}$, and $x_{0}$ was $0.6 \mathrm{~m}$. In addition, according to the rock pressure theory [22] and above field monitoring, the length of key block B is about $30 \mathrm{~m}$, with an average thickness of $4.83 \mathrm{~m}$.

\subsection{Mechanical Principle of Stress Change of Coal Pillar in} Gently Inclined Coal Seam. After the 21011 working face was mined, the stress in the surrounding rocks of the 21015 entry was redistributed, and the abutment stress was carried by gob and solid coal; when the 21015 working face was mined, the abutment stress was carried by the coal pillar and solid coal. Under the influence of inclination, the horizontal stress was transferred to the coal pillar which became the main load carrier. Figure 7 presents the distribution of abutment stress.

It can be seen that in gently inclined coal seam, with the mining of 21015 working face, the main roof gradually rotates and sinks and forms the key block B analyzed in 4.2. Within this stage, front abutment stress increases sharply, and the coal pillar is the main bearing body; therefore, the deformation and stress of the coal pillar gradually reached the peak value and were obviously greater than those of solid coal. Additionally, in the process of abutment stress rebalance, the inclination angle affects the accumulation of the gob and limits the free space of the gob-side coal pillar. Therefore, the stress and strain of the gob-side coal pillar were obviously smaller than those of the entry side.

Previous research works have shown that horizontal stress exerted on the coal pillar is closely related to the size of the key block B and the degree of rotation [24]. Furthermore, the inclination significantly affects the stability of the coal pillar. Generally, with the increase of dip angle, the horizontal force will inevitably lead to a sharp increase. The above proves that in inclined coal seam, the inclination angle affects the uneven distribution of horizontal stress, and this uneven horizontal stress environment is the internal cause of entry asymmetric deformation failure.

In Figure $6, \tau_{x y}$ is the shear stress at the interface between coal seam and roof and floor; $\sigma_{y}$ is the $y$-direction stress; $P_{x}$ is the gob-side resistance.

4.4. Analysis of Numerical Simulation Results. After the entry was excavated, the original structure of the stratum was destroyed. Surrounding rock asymmetric deformation was related to rotary horizontal extrusion of key block B influenced by inclination. Figure 8 shows horizontal stress distribution of coal pillar in gently inclined coal seam. It can be seen that the horizontal stress in the coal pillar generally shows a trend of decreasing and then increasing with height changes. The specific performance is as follows. (1) Entry excavation stage: the horizontal stress in the middle of the coal pillar was significantly lower than that of the top and bottom, and the stress of the entry-side coal pillar was obviously greater than that of the goaf-side coal pillar. (2) Mining stage: similar to the entry excavation stage, the horizontal stress in the middle of the coal pillar was significantly lower than that of the top and bottom, and the stress on both sides of coal pillar was basically the same.

In order to further comprehend the effect of inclination on coal pillar asymmetric deformation failure, Figure 9 presents the displacement distribution of coal pillar in gently inclined coal seam. It can be seen that the horizontal displacement of gob side of coal pillar generally shows a decreasing trend, while the entry side generally increases and then decreases with height changes. The specific performance is as follows. (1) Entry excavation stage: the deformation of the upper and middle part of the coal pillar is significantly larger 


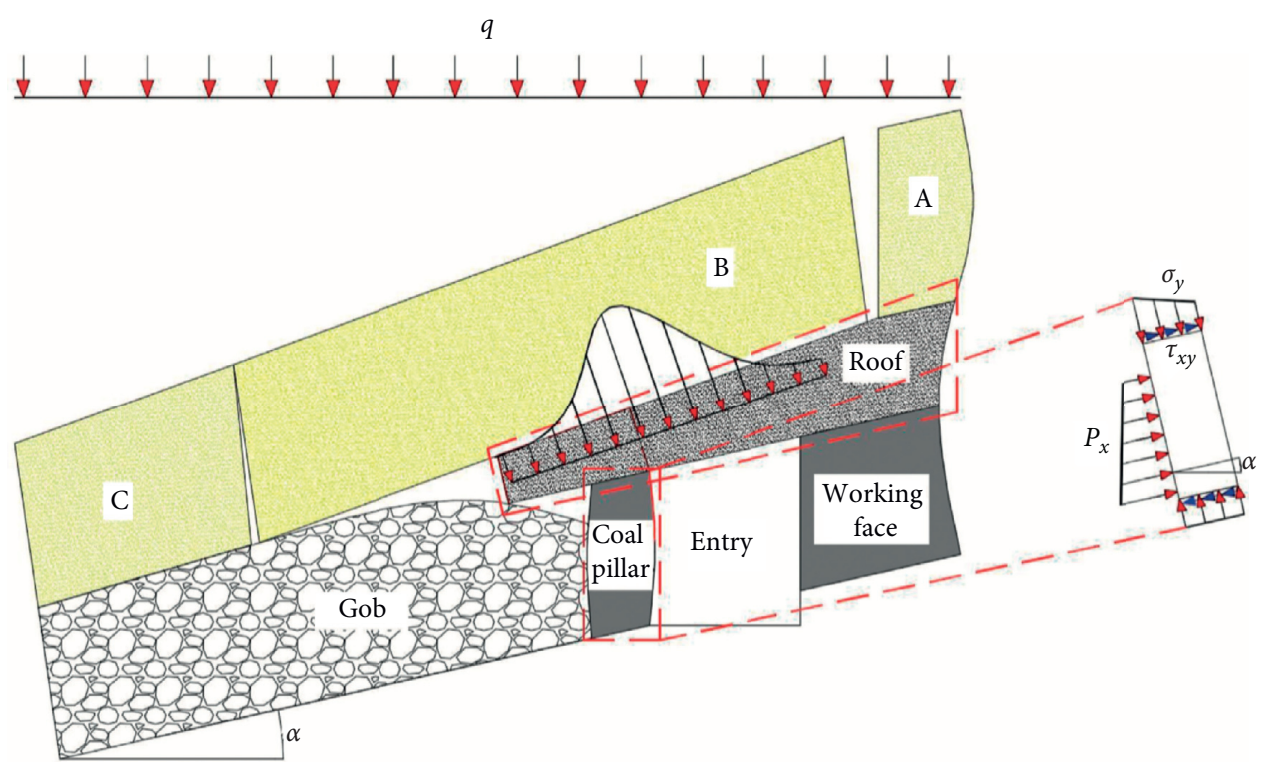

Figure 7: Distribution of side abutment stress.

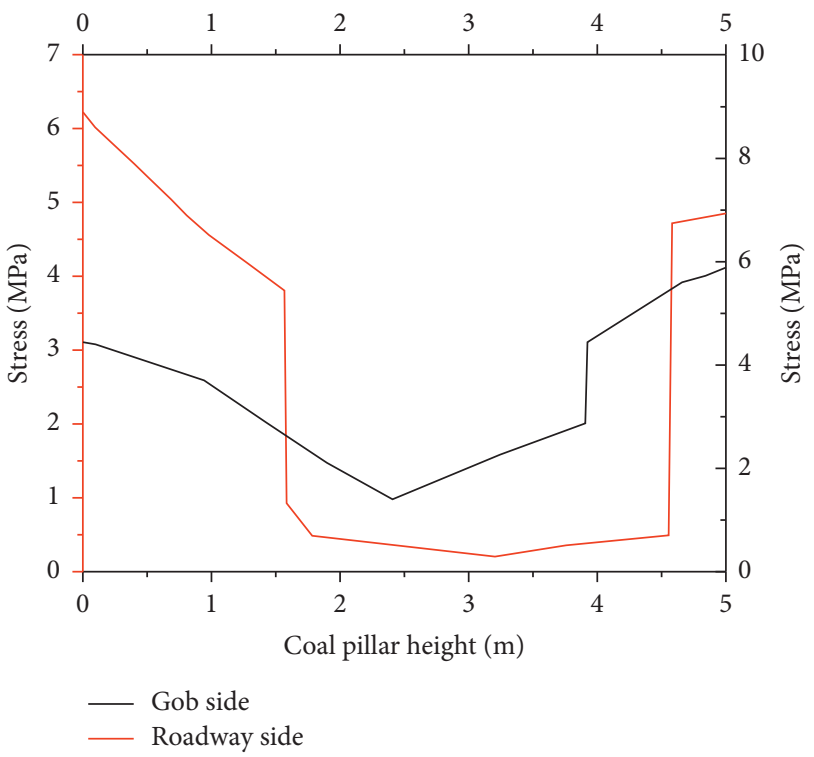

(a)

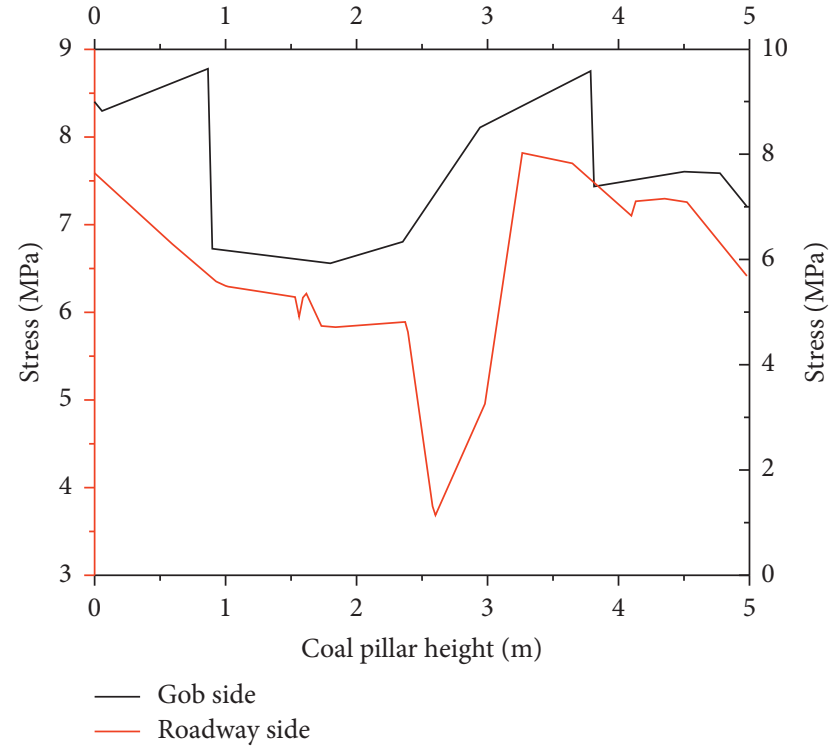

(b)

Figure 8: Horizontal stress distribution of coal pillar. (a) Excavation of 21015 entry. (b) Excavation of 21015 working face mine.

than that of the bottom, and the deformation of the entry-side coal pillar is obviously larger than that of the gob-side coal pillar. (2) Mining stage: similar to the entry excavation stage, the deformation in the middle of the coal pillar was significantly lower than that of the top and bottom, and the deformation on both sides of coal pillar is basically the same.

The analysis was as follows:

(1) During the entry excavation, the overlying strata have not broken, and the abutment pressure was carried by the gob and solid coal. The horizontal stress of the coal pillar basically showed a low degree. With the mining of working face, the overlying strata gradually fractured and rotated, and the pressure of Key block B was carried by the coal pillar and solid coal as shown in Figure 10. The horizontal stress decreased and then increased from the shallow part of roof to coal pillar, which presented an obvious uneven stress distribution. Moreover, because of the crushing and expending effect of immediate roof, the gob was sufficiently filled and relatively decrease breaking and deflection degrees of the gob-side coal pillar.

(2) Comparing the variations of horizontal stress and deformation of coal pillar during entry excavation and working face mining, when the inclination 


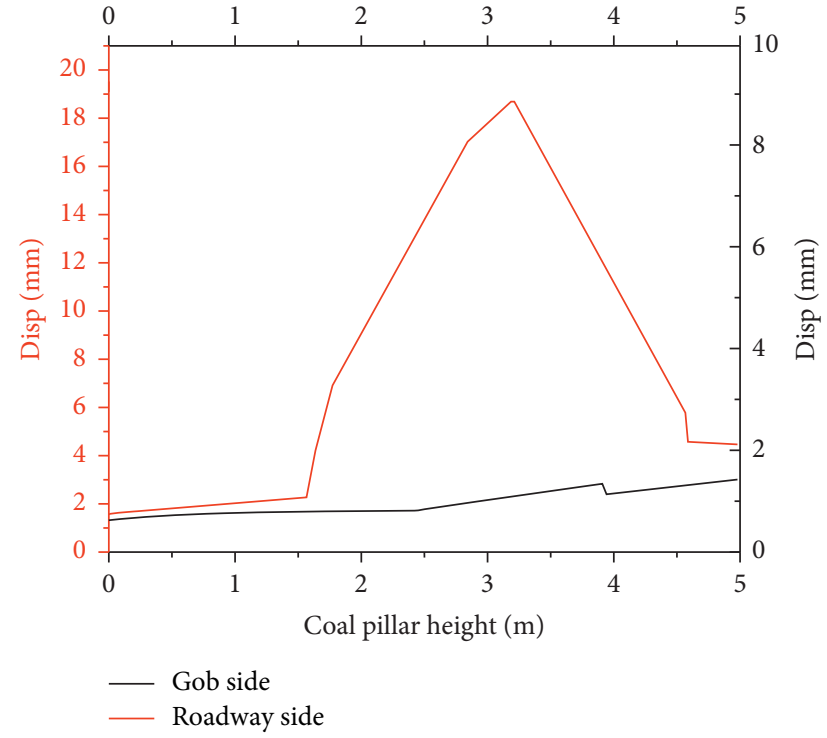

(a)

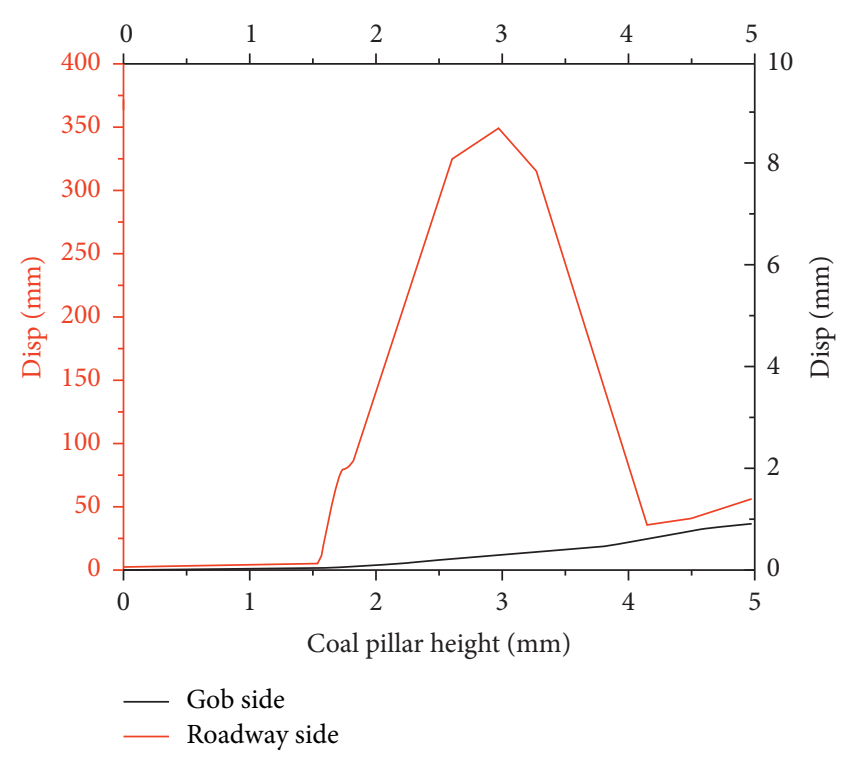

(b)

FIGURE 9: Horizontal displacement distribution of coal pillar. (a) Excavation of 21015 entry. (b) Excavation of 21015 working face.

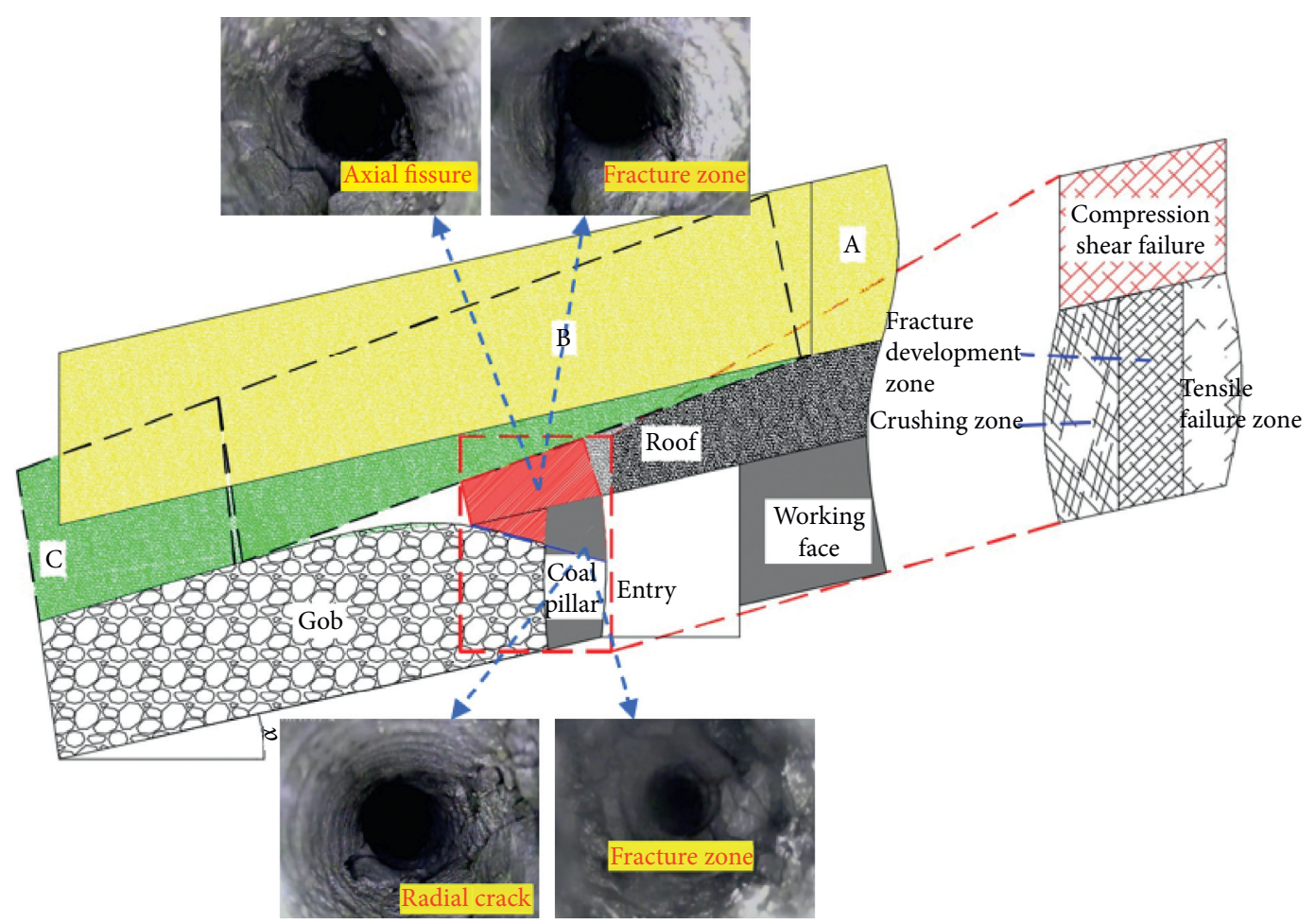

FIgUre 10: Plastic damage diagram of the coal pillar.

increases, the key block $\mathrm{B}$ may be deformed and unstable, which results in coal pillar expansion, squeezing, breaking, and deformation. It is clear that the inclination directly affects the rotation motion of the overlying strata and intensifies the uneven stress and deformation situation of the surrounding rock of the entry, which was basically consistent with the stress characteristics obtained from Section 4.3.

\section{Stability Control Technique of Entry Influenced by Inclination}

The asymmetric deformation failure characteristics of entry surrounding rock in gently inclined coal seam were caused by uneven external forces. The symmetric supporting structures have high bearing capacity under the uniform external force, but it will fail under the action of uneven 


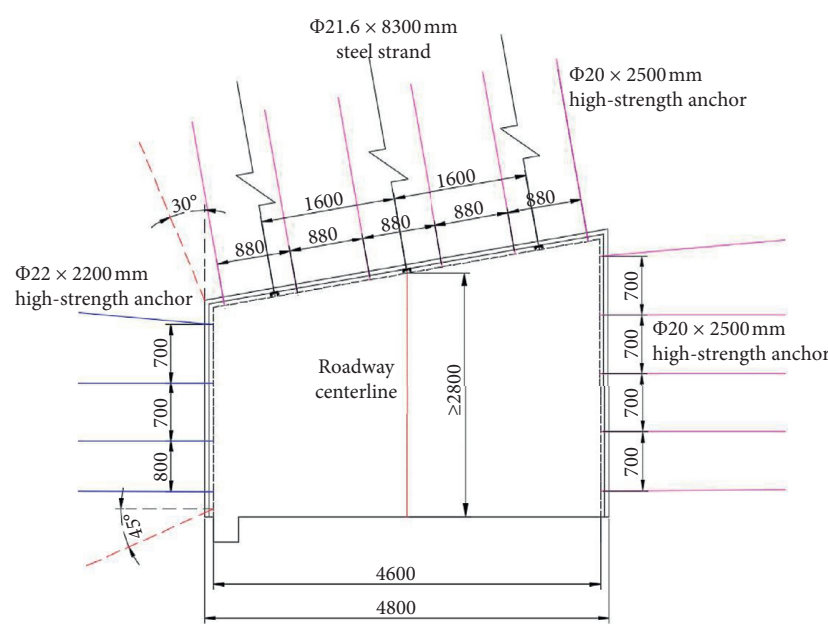

(a)

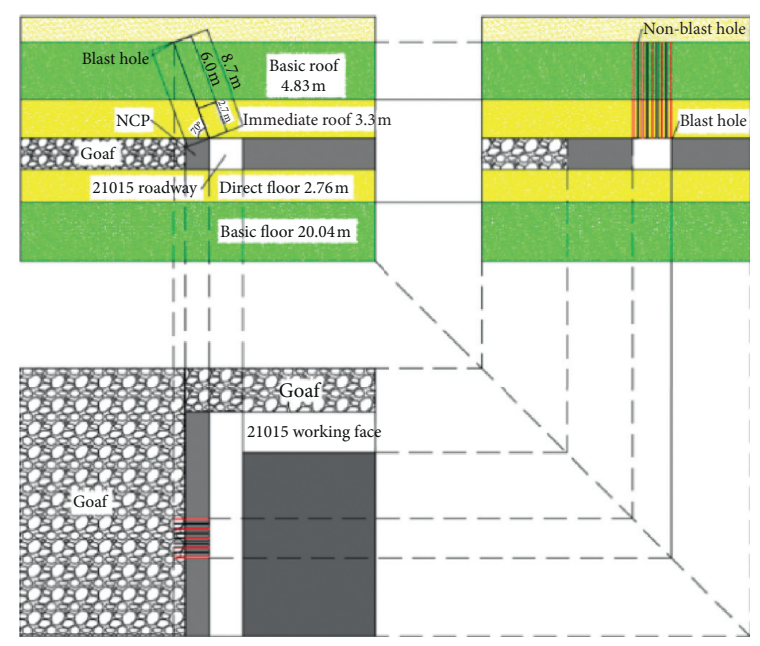

(b)

FIGURE 11: Stability control arrangement of entry. (a) Optimized support schemes and parameters. (b) Layout of the blast hole.

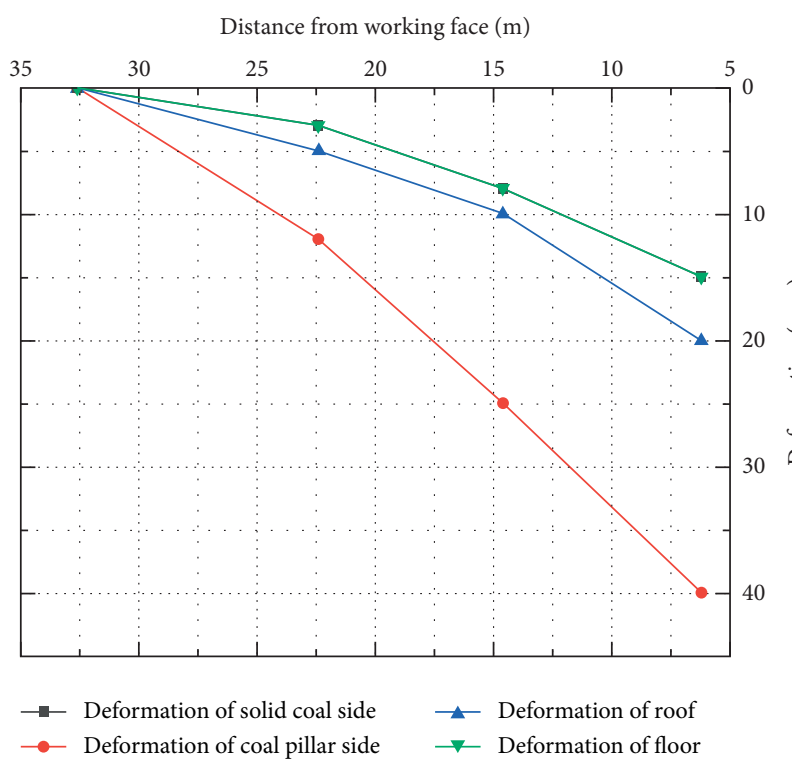

(a)

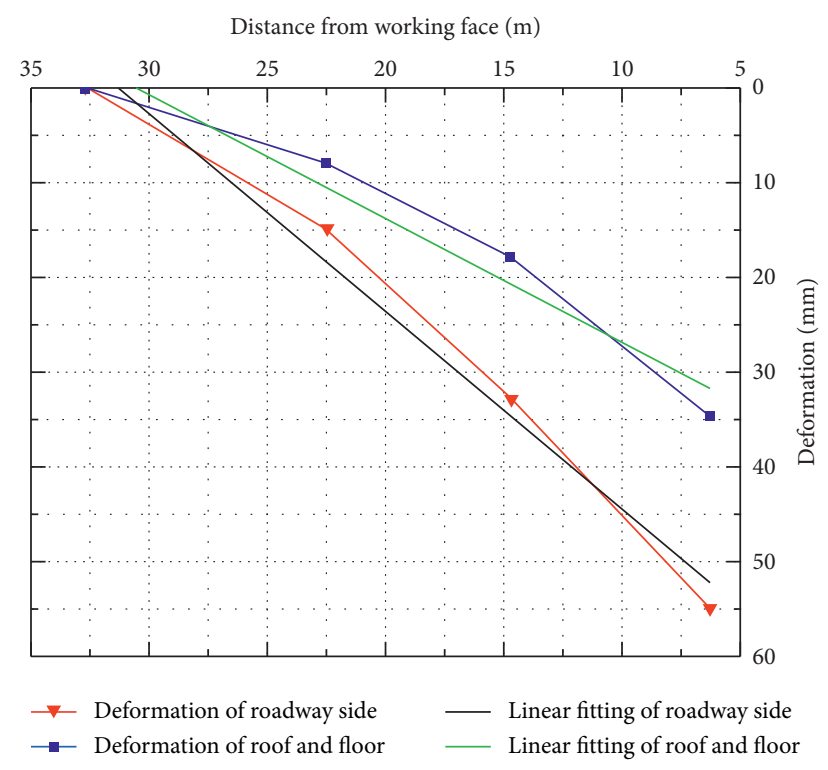

(b)

FIGURE 12: Deformation monitoring of surrounding rock.

external force [25]. The asymmertric control that can be effectively coordinated with roadway surrounding rock influenced by inclination should be put forward. Moreover, human intervention in the evolution of the roof overburden structure was an effective technique for reducing the stress and deformation of the entry influenced by inclination.

5.1. Entry Stability Control Method. To ensure the normal use of the mining entry under the influence of gently inclined coal seam, it is necessary to adopt a collaborative control technology of roof cutting for pressure relief and support strengthening. According to the instability mechanism of the entry under the influence of gently inclined coal seam, the following methods were proposed for controlling entry stability: (1) relieve the uneven external forces of entry surrounding rock; (2) improve the support strength of weak structure such as coal pillars and solid coal rib; and (3) strengthen the overall structure of the roof and deep rock formations.

5.2. Entry Stability Control Technology. According to the foregoing entry stability control method, the optimized 
support schemes and parameters are presented in Figure 11(a). Considering the roof and the advancing speed of the working face, the cutting height was $8.13 \mathrm{~m}$, the drilling depth was $8.70 \mathrm{~m}$, the diameter was $38 \mathrm{~mm}$, the angle was $20^{\circ}$, the spacing was $600 \mathrm{~mm}$, the sealing length was $2.7 \mathrm{~m}$, the loaded length was $6 \mathrm{~m}$, the explosive load per meter was $0.45 \mathrm{~kg}$, and the shaped charge tube was used for forward blasting and series detonation.1\#, 3\#, 5\#, 7\#, 9\# were blasting holes and 2\#, 4\#, 6\#, 8\# were pilot holes, as shown in Figure 11(b).

5.3. Application Effect. To verify the effect of the entry asymmetric control form of the surrounding rock, surface displacement monitoring was set up to monitor the deformation of roadway surrounding rock during the mining process. The measurement results are shown in Figure 12. The maximum convergence of the coal pillar rib was $40 \mathrm{~mm}$, the solid coal rib was $15 \mathrm{~mm}$, the roof was $20 \mathrm{~mm}$, and the floor was $15 \mathrm{~mm}$, respectively. Compared with the control effect before repairing, the maximum deformation of coal pillar rib has been reduced by $38 \%$, the maximum deformation of solid coal rib has been reduced by $53 \%$, and the deformation of roof and floor was basically unchanged. It can be seen that entry deformation was significantly reduced and there was no surge in deformation rate, which showed that the collaborative control method of roof cutting for pressure relief and support strengthening satisfied the long-term stability of entry. In addition, no roof fall, collapse, or rib spalling occurred during the service period of the entry. The surrounding rock control method provides a reference for similar asymmetric deformation entry affected by inclination.

\section{Conclusions}

Based on the above field investigation, theoretical analysis, and numerical simulation results, the conclusions can be summarized as follows:

(1) In gently inclined coal seam, the fracture line of the main roof was positioned above the coal pillar. Under the influence of inclination, horizontal stress was transferred to the coal pillar which was the main load carrier.

(2) Due to the influence of inclination, the overlying strata fracturing and rotation occur severely, the front abutment stress increases sharply, which is the internal cause of entry asymmetric deformation failure.

(3) According to asymmetric failure characteristics of entry, collaborative control technology of roof cutting for pressure relief and support strengthening is put forward.

\section{Data Availability}

The experimental test data used to support the findings of this study are included within the article.

\section{Conflicts of Interest}

The authors declare that they have no conflicts of interest.

\section{Acknowledgments}

The authors gratefully acknowledge the financial support provided by the National Natural Science Foundation of China (51674242 and 52074266).

\section{References}

[1] W. J. Guo, H. L. Wang, and S. J. Chen, "Coal pillar safety and surface deformation characteristics of wide strip pillar mining in deep mine," Arabian Journal of Geosciences, vol. 9, no. 2, p. 9, 2016.

[2] B. Du, C. Liu, J. Yang et al., "Abutment pressure distribution pattern and size optimization of coal pillar under repeated mining: a case study," Arabian Journal of Geosciences, vol. 13, no. 23, 2020.

[3] Z. Ma, C. Chen, X. Liang et al., "Field and numerical investigation on the stability of coal pillars of gob-side entry driving with top coal," Arabian Journal of Geosciences, vol. 13, no. 22, pp. 1-11, 2020.

[4] W. D. Wu, J. B. Bai, X. Y. Wang et al., "Numerical study of failure mechanisms and control techniques for a gob-side yield pillar in the sijiazhuang coal mine, China," Rock Mechanics and Rock Engineering, vol. 52, no. 6, 2018.

[5] Z. Xia, Q. L. Yao, G. S. Meng et al., "Numerical study of stability of mining roadways with $6.0-\mathrm{m}$ section coal pillars under influence of repeated mining," International Journal of Rock Mechanics and Mining Sciences, vol. 138, 2021.

[6] H. W. Zhang, Z. J. Wan, Z. Y. Ma et al., "Stability control of narrow coal pillars in gob-side entry driving for the LTCC with unstable overlying strata: a case study," Arabian Journal of Geosciences, vol. 11, no. 21, 2018.

[7] Y. Zhang, Z. J. Wan, C. L. I. Fu et al., "Large deformation mechanism of roadway driving along goaf under unstable overlying rock strata," Journal of Mining \& Safety Engineering, vol. 29, no. 4, pp. 451-458, 2012.

[8] B. Yu, Z. Zhang, T. Kuang, and J. Liu, "Stress changes and deformation monitoring of 1 coal pillars located in weak ground," Rock Mechanics and Rock Engineering, vol. 49, no. 8, pp. 3293-3305, 2016.

[9] E. Esterhuizen, C. Mark, and M. M. Murphy, "Numerical model calibration for simulating coal pillars, gob and overburden response," in Proceedings of the 29th international conference on ground control in mining, pp. 46-57, Morgantown, WV, USA, July 2010.

[10] A. J. Das, P. K. Mandal, P. S. Paul, and R. K. Sinha, "Generalised analytical models for the strength of the inclined as well as the flat coal pillars using rock mass failure criterion," Rock Mechanics and Rock Engineering, vol. 52, no. 10, pp. 3921-3946, 2019.

[11] W. Gao and M. Ge, "Stability of a coal pillar for strip mining based on an elastic-plastic analysis," International Journal of Rock Mechanics and Mining Sciences, vol. 87, pp. 23-28, 2016.

[12] S. H. Prassetyo, M. A. Irnawan, G. M. Simangunsong, R. K. Wattimena, I. Arif, and M. A. Rai, "New coal pillar strength formulae considering the effect of interface friction," International Journal of Rock Mechanics and Mining Sciences, vol. 123, Article ID 104102, 2019. 
[13] J. J. Dai, P. F. Shan, and Q. Zhou, "Study on intelligent identification method of coal pillar stability in fully mechanized caving face of thick coal seam," Energies, vol. 13, no. 2, 2020.

[14] S. F. Liu, Z. J. Wan, Y. Zhang et al., "Research on evaluation and control technology of coal pillar stability based on the fracture digitization method," Measurement, vol. 158, 2020.

[15] W. Gao, "Influence of interaction between coal and rock on the stability of strip coal pillar," Geomechanics and Engineering, vol. 16, no. 2, pp. 151-157, 2018.

[16] A. J. Das, P. K. Mandal, P. S. Paul, R. K. Sinha, and S. Tewari, "Assessment of the strength of inclined coal pillars through numerical modelling based on the ubiquitous joint model," Rock Mechanics and Rock Engineering, vol. 52, no. 10, pp. 3691-3717, 2019.

[17] A. J. Das, P. S. Paul, P. K. Mandal et al., "Investigation of failure mechanism of inclined coal pillars: numerical modelling and tensorial statistical analysis with field validations," Rock Mechanics and Rock Engineering, vol. 54, pp. 3263-3289, 2021.

[18] P. X. Zhao, G. Li, S. G. Li et al., "Analysis of size effect of mechanical characteristics of coal pillars gob-side entry in inclined thick coal seam," Journal of Mining \& Safety Engineering, vol. 36, no. 6, pp. 1120-1127, 2019, in Chinese.

[19] X. Z. Chen and M. Wang, "Research on surrounding rock deformation characteristics of gob-side entry driving in deep inclined coal seam and its control technology," Journal of Mining \& Safety Engineering, vol. 32, no. 3, pp. 485-490, 2015, in Chinese.

[20] S. Zhang, X. Wang, G. Fan, D. Zhang, and C. Jianbin, "Pillar size optimization design of isolated island panel gob-side entry driving in deep inclined coal seam-case study of Pingmei No. 6 coal seam," Journal of Geophysics and Engineering, vol. 15, no. 3, pp. 816-828, 2018.

[21] W. X. Huang, Study on the Mechanism of Water Breakout in the Mining Floor on High Pressurized Water in Chen Silou Coal mine, China University of Mining and Technology, Xuzhou, China, 2017, in Chinese.

[22] M. G. Qian, P. W. Shi, and J. L. Xu, Mine Pressure and Strata Control, China University of Mining and Technology Press, Xuzhou, China, 2010, in Chinese.

[23] J. L. Xu and J. F. Ju, "Structural morphology of key stratum and ITS influence on strata behaviors in fully-mechanized face with super-large mining height," Chinese Journal of Rock Mechanics and Engineering, vol. 30, pp. 1547-1556, 2011, in Chinese.

[24] Q. Y. Xu, Q. G. Huang, and G. C. Zhang, "Fracture and instability mechanism and control technology of a narrow coal pillar in an entry in fully mechanized caving mining under intense effect mining," Journal of Mining \& Safety Engineering, vol. 941, pp. 941-948, 2019, in Chinese.

[25] X. Xu, F. He, X. Li, and W. He, "Research on mechanism and control of asymmetric deformation of gob side coal roadway with fully mechanized caving mining," Engineering Failure Analysis, vol. 120, Article ID 105097, 2021. 